\title{
FILME JUÍZO: AS FRONTEIRAS ENTRE O REAL E O FICCIONAL NOS DOCUMENTÁRIOS
}

\author{
Jessica Ferreira Rodrigues
}

JUÍZO. Direção de Maria Augusta Ramos. Brasil, 2007. Produção Diler Trindade 2007.

\section{Introdução}

O presente trabalho visa analisar todos os aspectos e elementos que cerceam o documentário Juízo(2007) da cineasta Maria Augusta Ramos. Este filme pretende mostrar ao espectador todo o processo envolvendo a detenção de um menor, desde a sua prisão, passando pelo julgamento e sua permanência como interno do Instituto Padre Severino localizado na cidade do Rio de Janeiro. Como o Estatuto da Criança e do Adolescente pró́be a veiculação do rosto de menores infratores em imagens a documentarista lançou mão de diversos artifícios como a substituição dos menores por atores para que assim, o filme conseguisse ter uma maior veracidade junto as espectador.

Sendo assim, Juízo( 2007) levanta várias questões que vão desde elementos importantes na sua construção como a própria dinâmica que se dá dentro da história contada pela cineasta, a fim de obter termos mais didáticos resolvi dividir esta resenha em dois tópicos importantes para uma melhor compreensão do leitor: uma voltada para as técnicas utilizadas pela cineasta nas filmagens e outro para a história desenrolada no filme.

\section{Filme Juízo: as fronteiras entre o real e o ficcional nos documentários}

Certa vez Jean Luc Godard disse que "todos os grandes filmes de ficção tendem ao documentário, assim como todos os grandes documentários tendem a ficção[...] e quem opta a fundo por um encontra necessariamente o outro no fim do caminho"( SALLES, 2005) 
O documentário Juízo(2007) apresenta diversas particularidades envolvendo a sua realização que são congruentes com questionamentos envolvendo a Antropologia Visual e a realização dos filmes tidos como registros etnográficos. No Filme, Maria Augusta Ramos, por questões judiciais ${ }^{1}$, não pôde filmar o rosto dos menores que dariam depoimentos durante o julgamento. Tais julgamentos podem ser considerados a espinha dorsal do filme, pois é em cima de tais falas que a autora estrutura a dinâmica do documentário, para superar este entrave a cineasta buscou alternativas que ferissem menos o aspecto documentarista do filme, buscando, assim, legitimá-lo como uma reprodução da realidade.

É importante lembrar que a expectativa dos telespectadores em relação a este gênero de filme é sempre que nele exista uma representação da realidade, assim como Nichols ( 1997) definiu:

No Nível mais fundamental, trazemos a suposição de que os sons e as imagens do texto se originam no mundo histórico que compartilhamos. Em geral não foram concebidos exclusivamente para o filme. (NICHOLS, 1997)

Para suprir o impedimento legal da veiculação da imagem destes menores a autora optou por utilizar jovens que viviam em condições de pobreza para que eles pudessem reproduzir as falas dos menores, criando um jogo que nos leva a pensar sobre a dualidade entre: "O que é realidade? X O que é ficcional." Juízo (2007) ao mesmo tempo em que traz elementos de existência anteriores ao filme, sendo assim: o Instituto, os Internos, o Tribunal que já estavam lá quando Maria Augusta Ramos resolveu filmá-lo ele também traz cenas que são criadas especialmente para o filme como é feito no final, onde, a cineasta mostra atores interpretando os menores em suas casas ou até mesmo nas falas dos menores que também são reproduzidas através da interpretação de terceiros.

A fronteira entre realidade e ficção vai além das questões de linguagem, montagem, e recursos técnicos de filmagem que já demonstram uma intenção ou a participação da cineasta na

1 A Veiculação da imagem de menores infratores é vedada pelo Estatuto da Criança e do Adolescente.

INTRATEXTOS, Rio de Janeiro, 4(1): 298-303, 2012.

Página 299 
sua produção e passa a dialogar com a ficção/ realidade nas próprias cenas do filme. Se considerarmos a existência de um contrato simbólico em que o espectador de um documentário confie no diretor como este sendo o transmissor de uma realidade historicamente já existente, Maria Augusta Ramos rompe com essa premissa na metodologia de realização do filme ao criar cenas que são fundamentais para a sua existência e para o entendimento do telespectador.

João Moreira Salles em “A Dificuldade do documentário”(2005) vai além destas questões ao afirmar que todo filme pode ser, em determinada medida, considerado um documentário. Essa consideração, para ele, não depende do cineasta e sim do receptor, é a partir do olhar deste que irá surgir a classificação de um filme. Assim, podemos pensar que é nesta percepção que os recursos utilizados pela autora do filme agem. A idéia dela é que o telespectador reconheça em Juízo( 2007) um documentário, mesmo que as fronteiras entre a representação e a reprodução de uma realidade já dada sejam tênues.

A proposta da cineasta é gerar uma reflexão sobre o tema retratado, mas deixando ao receptor a liberdade de tirar as suas próprias conclusões, ou seja, Juízo(2007) não é um filme que apresente soluções ao problema, essa não parece ser a intenção. Maria Augusta deixa isso bem claro ao discutir em uma entrevista ao site Pílula Pop qual é o papel do documentário. Segue um trecho:

Pílula Pop: O documentarista deve retratar a realidade ou tentar mudá-la?

Maria Augusta Ramos: Tentar mudar a realidade? Jamais. Eu tento retratá-la o mais fielmente possível. Há uma representação, claro. É uma visão subjetiva minha, um retrato. Para mim, essa idéia de que o documentário é objetivo não existe. Nem a mídia é objetiva. Eu faço escolhas a cada momento que edito. O documentário não é só estética, é também sobre ética. Em cada corte, existe uma questão ética: você pode transformar aquela realidade ou fundamentar uma tese. O Michael Moore faz isso: ele tem uma tese " $x$ " e aí faz um documentário para prová-la, que é a maneira dele fazer cinema. A minha é diferente. Eu tento retratar a realidade de maneira que leve o público a pensar, a refletir sobre ela por si só. Por isso, é um cinema que observa, mais reflexivo, que exige uma distância entre o público e os personagens retratados. E essa distância é criada pelo trabalho de câmera, de edição. Tem um tempo, um ritmo: a 
câmera nunca se aproxima muito, sempre estática, frontal, sem planos subjetivos dos personagens. Tudo isso faz o meu estilo de cinema. ${ }^{2}$

David MacDougall (1997), ao trabalhar questões inerentes aos filmes etnográficos afirmou que o filme nunca é somente fruto de quem o realizou, ele é a construção de quem está sendo retratado também. É como se fosse um jogo de forças entre os dois pólos e o resultado disto seria o filme. Transmitindo este conceito para o documentário é importante pensarmos até que ponto a atuação dos indivíduos não é alterada com a presença de uma câmera.

Dentro deste mesmo exercício de reflexão é possível pensarmos na atuação da Juíza Luciana Fiala, responsável pelos julgamentos dos menores. O momento do julgamento é fundamental no Filme, pois é nele que os menores ganham voz através da interpretação que os atores fazem de suas falas. É nele, também, que podemos ver a participação do Judiciário e dos pais, duas figuras que representam ou deveriam representar autoridades diante do menor infrator. Não obstante é assim que a Juíza age, de maneira enérgica, suplantando, muitas vezes, a presença dos pais que, por vezes, aparecem presentes nas cenas. Essa atuação intensa do juíza, leva a questionamentos referentes ao seu posicionamento e imparcialidade diante das câmeras. Ao ser questionada sobre tal assunto em um chat realizado pelo site da UOL, a Juíza( Luciana Fiala) respondeu a questão da seguinte maneira:

PERGUNTA: (04:21:28) lua: Luciana, a senhora não acha que representou o tempo todo?

RESPOSTA DA JUÍZA (04:26:34) Maria Augusta Ramos e Luciana Fiala: lua, todo mundo diz isso. Eu faço audiência exatamente daquele jeito. Não sou atriz e nem quero ser, sou juíza e quero continuar assim. Ali é o meu jeito de ser, são broncas em que me

\footnotetext{
${ }^{2}$ Disponível em http://www.pilulapop.com.br/ressonancia.php?id=95
} 
sinto na obrigação de dar. Às vezes tenho que fazer o papel de mãe porque falta tudo, limites, por exemplo. (Luciana). ${ }^{3}$

Ao afirmar que, às vezes, tem que fazer o papel de mãe, a juíza já supõe uma representação no seu próprio cotidiano dentro dos julgamentos, ou seja, ser Juíza já é um papel que ela representa e é este que é retratado no filme, além deste aspecto podemos ver que não há fronteiras delimitadas entre o seu de papel de juíza e aquilo que vemos como uma função moral, onde ela busca "educar" o menor a fim de que ele apreenda os seus valores morais, em específico. Juízo(2007), portanto, não trabalha somente com a representação de atores amadores, mas também com a própria representação da vida cotidiana de indivíduos que encarnam personagens, o menor infrator que interpreta da maneira que dá a sua inocência, a Juíza que interpreta ou que assume uma posição moralista diante do acusado. O que é real, o que é ficção? Nunca saberemos dentro de uma realidade que já é subjetivada.

Juízo (2007) é um filme que trabalha com diversos casos de jovens, internos do Instituto Padre Severino. Ele mostra todo o processo que um jovem passa desde a sua internação até o julgamento, este último em um número de cenas consideravelmente maior. Dentro da dinâmica do julgamento vemos a figura marcante da juíza Luciana Fiala que conduziu com, exceção de um, os julgamentos. No filme fica claro o seu papel de questionar os adolescentes e até mesmo o as função moral de lhes "dar broncas”, ironizar suas declarações, assim como aconselhar.

A presença de Luciana é tão marcante que o Defensor público torna-se apagado diante das decisões da juíza. No tribunal tudo parece um procedimento burocrático, chama-se o adolescente, a juíza lê os autos do processo, questiona o interno, aplica o "puxão de orelha" e chama o próximo. Há um distanciamento entre os poderes, não somente entre o defensor, a juíza e a promotora como também entre o poder executivo e legislativo. A socióloga Vera da Silva Telles classifica este afastamento como um abismo:

\footnotetext{
${ }^{3}$ Disponível em: http://tc.batepapo.uol.com.br/convidados/arquivo/cinema/juiza-e-maria-augusta-ramosdiretora-de-juizo-conversam-sobre-documentario.jhtm
} 
No entanto, ao mostrar os atores em cena, ela nos faz ver no mesmo ato, o absurdo exposto no brutal abismo entre os operadores da justiça e os adolescentes. Abismo de códigos, de linguagem, de mundos que não se comunicam, ou melhor, que só se encontram sob a lógica punitiva que comanda toda a encenação. (TELLES, 2007)

É sobre tal abismo que versa juízo, um filme que já utiliza um trocadilho no seu próprio nome: De quem seria afinal o Juízo? Seria um filme sobre o sistema judiciário ou seria sobre adolescentes infratores? Para Maria Augusta Ramos o filme é sobre a sociedade brasileira.

\section{Referências Bibliográficas:}

MACDOUGALL, David. De quem é essa história? IN Cadernos de Antropologia e Imagem. V.5, N.2, UERJ, 1997, PP 93-106

NICHOLLS, Bill. “Que tipo de documentários existem?” E “ Em que os documentários diferem dos outros filmes? IN Introdução ao documentário. Campinas: Papirus, 2005, 135-177 e 47-71.

SALLES, João Moreira. "A dificuldade do documentário". IN Martins, Ecjer \& Caiuby Novais( orgs) O Imaginário e o Poético nas Ciências Sociais. Bauru: EDUSC, 2005 PP 57-72.

\section{Videografia:}

JUÍZO. Direção de Maria Augusta Ramos. Brasil, 2007. Produção Diler Trindade 2007. DVD(90min) colorido. 